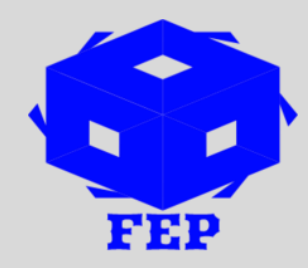

\title{
ANALYSIS OF RESTRUCTURING, AND RESCHEDULING OF THE DEBT
}

Erdem Aksoy ${ }^{1}$, Gulfem Dilek ${ }^{2}$

${ }^{1}$ Gaziantep University, Turkey

*Corresponding Author: Erdem Aksoy

Article Received: 23-09-19

Accepted: 30-12-19

Published: 10-01-20

Licensing Details: Author retains the right of this article. The article is distributed under the terms of the Creative Commons Attribution-Non Commercial 4.0 License (http://www.creativecommons.org/licences/by-nc/4.0/) which permits non-commercial use, reproduction and distribution of the work without further permission provided the original work is attributed as specified on the Journal open access page.

\begin{abstract}
The paper investigates a semantic confusion about rescheduling and restructuring of a public debt. There issues are not related to the default. The rescheduling refers to the swap of debt towards long term and restructuring as a change in the denomination of the debt. The paper conducts empirical evidence for the swaps involved using the econometrics exercise. The findings of the paper are that a swap of short term replacing long term debt is continuously implemented by the central bank of Turkey. Lengthening the maturity of the debt seems to be covert policy of debt management. The paper reported that another covert policy is that bank often swap local debt for dollar or euro debt or change the currency issuance or restructure it. Even though, the bank is involved in these covert policies, the central bank is publishing this data and making no efforts for hiding such information. Thus, we assume that the rating agencies are aware about these debt transactions due to the fact that these transactions are conducted in market prices. The covert policies are good enough as they seems to be working and should be regarded as such without regard to their interest cost.
\end{abstract}

Keywords: Rescheduling, Restructuring, Public Debt, Turkey

\section{INTRODUCTION}

The Turkish government recently announced about restructuring and rescheduling the Turkish debt in the awake of bringing changes in the country's fiscal and monetary policies. The announcement received warm welcome and also caused some reaction. The problem is 
that rescheduling and restructuring of debts may have negative effects on the sovereignity of the country and may deter the foreign investors. For better understanding this situation, there is requirement to understand the rescheduling and restructuring in details. In the domain of foreign market participants, restructuring a debt is about paying interest rate dues on the debt and is usually a preamble to financial bankruptcy and distress. Restructuring also refers to the selective defaults geared to the composition of the debt while some borrowings are chosen to be in default, while, other remains untouched. Thus, we can say that both terms are closely related to eventual bankruptcy and default. Accordingly, in the local context, the rescheduling is shorter to longer maturities and foreign debt is restructured from a denomination in Turkish Lira to a denomination in US dollars. This policy is supposing to be easing the burden of liquidity and reducing the cost of recurring debt roll-overs of the government; while, the later policy will be supposed to reducing the service of the public debt because borrowing rates are lesser on US dollars against Turkish currency. Thus, we can say that there is semantic difference in these terms. The paper presents the evidence that government is involved in rescheduling and restructuring the debt since the early 1990s. Furthermore, our analysis suggests that rating agencies have implicitly approved this policy of swap transactions of Turkish debt and were aware of this situation. Given the nature of the terms, it is important that these terms are properly defined since both terms are used interchangeably. Rescheduling in local context is set to mean a swap of short term debt to long term debt. In such situation, the government is increasing the average maturity of the debt from short term to the long term debt. This implies that there is negative association between short term debt and long term debt.

The other term is restructuring which refers to the swap of debt denominated in Turkish currency for a debt in Euro bonds. Euro bonds are bonds in foreign currency main in dollar terms and not necessarily issued in Euro currency. The practice is to quote Eurodollars in dollars and not in Euros. We however found that there is negative association between evolution of Euro bonds and local bonds. The rescheduling and restructuring can be done at the same time with swap of short term local debt to longer term Euro bonds. However, in general, issues of Euro bonds are for a longer maturity than issue of local bonds.

For econometric verification, we chose 2 stage least square procedure. For this purpose, the simultaneity bias needed to be addressed which occurs when euro bonds are sold for local bonds and because local bonds are also sold for Euro bonds, there is a two-way causality between the both refers to simultaneity bias. The regression in this 
case can be considered as demand function since it include the business and consumer confidence and local and foreign interest rates.

\section{LITERATURE REVIEW}

There is lack of empirical evidence on the determination of the optimal management of the public debt and the relative preference of policy makers to trade off maturity and currency of denomination. Barro (1999) reports that for optimal debt management, three criteria can be used including increasing public outlays, financing during wartime, and tax smoothing. Another issue is to minimize the cost of servicing. Greenwood, et al., (2014) states that debt management is about how government minimize the debt servicing and reducing the fiscal risk of frequent refinancing uncertainties. The first intent favors a differential demand for short term borrowing which have usually a lower cost and this seems to be correct since it creates upwards sloping curve. However, with this approach, there are two issues including the higher risk of refinancing cost and bank runs. Bank run is situation when investors collide to impose dire constraints on interest rates. The refinancing arises when interest rates in the future have a uncertain path and cannot be known as ex ante. In situation when empirical models which attempts to predict future interest rates break down and fail drastically. Interest rates are the least predictable series when it comes to macroeconomics.

In corporate finance, higher return is rewarded for new debts obtained by a firm. If one borrows from corporate finance the concept that debt serves to monitor and insure discipline of senior managers to minimize on agency cost, then it can be argued that for public debts roll-vers, there will be negative externality. Thus, the banker's position is ambiguous. Higher rates can attract more deposits but it can also can scare away demands for loans. From politicians point of view, a lower interest rates is in their favor since it creates higher business activity in a country. Thus, the independence of the central bank is precariously threatened. Mostly, central bank chiefs are appointed by executive government with their own political agenda in mind. How a government manage debts optimally is also a policy issue. The issue is about selection of debt in local currency and debt in foreign currency. A study by Amstad, et al., (2018) investigated the debt denomination for various currencies. The findings were that local currency debt is considered safer compare to the foreign currency debts. In Turkish case, the central bank is tilting funds from local debt towards foreign 
debt. The outcome is that it is increasing the maturity of debt reducing possible liquidity constraints.

\section{Empirical Studies Results}

From the central bank data, we used the following seven variables which are found to be unconstrained version of the model. The variables include net local debt, gross local debt, long term local debt, total debt in foreign currency, coincident indicator, and weighted average interest rate on deposits in domestic currency. The short term local debt is calculated by netting either gross local debt or long term local long term from net local debt. The difference between net debt and gross debt is that the gross debt exclude public sector deposits at the commercial and central bank; while, net debt include these. The coincident indicator is consumer and business confidence index as compiled by the central bank which we used as a proxy for a real scale variable. The results consist of two parts. Net local debt is the first part and the gross local debt is the second. Part one consist of two specifications consisting of net local debt and long term local debt. The second part consist of net local debt and debt in foreign currency. In other terms, the specifications differ by maturity and by currency of denomination for the two measures of local debt, net local debt and gross local debt.

We applied two stage least square for avoiding simultaneity bias in the model. Both models are similar. Coincident indicators longs are included in the regression initially and the $\log$ of the domestic currency interest rate, and the log of the foreign currency interest rate. Thus, all the reported empirical results omitted these other two variables. Two diagnostics are calculated for each regression. One is the conditional heteroscedasticity and the other is serial correlation. Since our data is time series so these tests are required. We used the Ljung-Box Q-statistics is used for testing the serial correlation on the lags of the residuals. 24 month is chosen for the lag length. Ljung-Box Q-statistics is used for testing the conditional heteroscedasticity. For this test, the lag length is also 24 months.

The central bank publishes a data series for long term local debt. For calculating indirectly the short term net debts, two estimates are used including the gross local debt and the net local debt. Table 1 takes up the statistical results of a regression between short term local debt and long term local debt in first-differences of the longs, a regression where the short term local debt is calculated by subtracting the long term local debt from net local debt. In table 3, the calculations of short term local debt from subtracting long term local debt from gross local debt. 
Table 1

2SLS of the relation between long and short term debt (rescheduling), based upon Net Local Debt (NLD)

Dependent Variable: (LOG(NLD))- (LOG(LTLD))

Method: Two-Stage Least Squares

Sample (adjusted): 1995M03 2019M03

Included observations: 289 after adjustments

Instrument specification: (LOG(NLD(-1))) (LOG(LTLD(-1)))

LOG(R-\$(-1)) LOG(R-LBP(-1)) LOG(CI(-1))

Constant added to instrument list

\begin{tabular}{|c|c|c|c|c|}
\hline Variable & Coefficient & Std. Error & t-Statistic & P-value \\
\hline $\mathrm{C}$ & -0.077884 & 0.0089767 & -1.78674 & 0.0543 \\
\hline (LOG(LTLD)) & -0.787866 & 0.088764 & -8.34334 & 0.0000 \\
\hline LOG(R-LBP) & 0.078787 & 0.004545 & 3.33434 & 0.0110 \\
\hline R-squared & 0.45455 & \multicolumn{2}{|c|}{ Mean dependent variable } & -0.001592 \\
\hline Adjusted R-squared & 0.43566 & \multicolumn{2}{|c|}{ S.D. dependent variable } & 0.027551 \\
\hline S.E. of regression & 0.07876 & \multicolumn{2}{|c|}{ Sum squared residuals } & 0.134287 \\
\hline F-statistic & 45.53753 & \multicolumn{2}{|c|}{ Durbin-Watson statIstic } & 2.047498 \\
\hline P-value: F-statistic & 0.000001 & \multicolumn{2}{|c|}{ Second-Stage SSR } & 0.186167 \\
\hline J-statistic & 4.56566 & \multirow{2}{*}{\multicolumn{2}{|c|}{ Instrument rank }} & 6 \\
\hline P-value: J-statistic & 0.331722 & & & \\
\hline
\end{tabular}

Notes: NLD is Net Local Debt; LTLD is Long Term Local Debt; R-LBP is the domestic interest rate; R-\$ is the US dollar foreign interest rate; and CI is the Coincident Indicator. LOG stands for the natural logarithm. is the firstdifference operator.

Table 2

Ljung-Box Q-statistics

\begin{tabular}{lllllllll}
\hline & \multicolumn{3}{c}{ On residuals } & & & \multicolumn{2}{l}{ On residuals squared } \\
\cline { 2 - 6 } lag & AC & PAC & Q-Stat & P-value & AC & PAC & Q-stat & P-value \\
\hline 1 & -0.066 & -0.065 & 0.555 & 0.767 & -0.097 & -0.055 & 0.5655 & 0.566 \\
3 & 0.097 & 0.055 & 1.5795 & 0.557 & -0.055 & -0.055 & 0.5566 & 0.769 \\
3 & 0.555 & 0.555 & 6.7775 & 0.177 & 0.165 & 0.161 & 6.6955 & 0.090 \\
6 & -0.055 & -0.565 & 6.7677 & 0.501 & 0.067 & 0.056 & 7.1650 & 0.159 \\
5 & 0.565 & 0.555 & 15.177 & 0.055 & 0.000 & 0.015 & 7.1650 & 0.510 \\
6 & -0.065 & -0.097 & 15.915 & 0.066 & 0.065 & 0.056 & 7.6716 & 0.565 \\
7 & 0.055 & 0.065 & 16.167 & 0.067 & -0.050 & -0.065 & 7.9670 & 0.557 \\
7 & -0.666 & -0.097 & 15.075 & 0.057 & -0.060 & -0.066 & 7.6575 & 0.595 \\
9 & 0.065 & 0.066 & 15.666 & 0.079 & 0.067 & 0.055 & 9.0907 & 0.659 \\
10 & 0.056 & 0.065 & 16.675 & 0.075 & -0.016 & -0.010 & 9.1707 & 0.516 \\
11 & 0.055 & 0.065 & 16.766 & 0.115 & -0.059 & -0.015 & 9.6556 & 0.575 \\
13 & -0.066 & -0.097 & 17.570 & 0.159 & -0.007 & -0.017 & 9.6595 & 0.665 \\
13 & -0.009 & 0.006 & 17.597 & 0.175 & -0.055 & -0.055 & 9.7655 & 0.715 \\
16 & 0.055 & 0.006 & 17.765 & 0.516 & -0.009 & -0.006 & 9.7759 & 0.777 \\
15 & 0.055 & 0.065 & 17.957 & 0.566 & 0.007 & 0.007 & 9.7066 & 0.755 \\
16 & 0.065 & 0.051 & 17.596 & 0.501 & -0.007 & 0.005 & 9.7555 & 0.776 \\
17 & 0.055 & 0.056 & 17.656 & 0.561 & -0.059 & -0.051 & 10.500 & 0.791 \\
17 & 0.097 & 0.060 & 19.966 & 0.556 & 0.157 & 0.155 & 15.519 & 0.660 \\
19 & -0.055 & -0.017 & 19.977 & 0.595 & -0.059 & -0.056 & 15.577 & 0.675 \\
30 & 0.500 & 0.075 & 55.150 & 0.575 & 0.056 & 0.060 & 15.757 & 0.755 \\
31 & -0.055 & -0.057 & 55.506 & 0.555 & -0.057 & -0.065 & 16.006 & 0.769 \\
\hline
\end{tabular}




\begin{tabular}{lllllllll}
\hline 33 & 0.077 & 0.095 & 35.605 & 0.377 & -0.003 & -0.007 & 16.006 & 0.716 \\
33 & 0.060 & -0.005 & 35.697 & 0.315 & 0.063 & 0.056 & 17.373 & 0.796 \\
36 & 0.077 & 0.113 & 37.376 & 0.367 & 0.051 & 0.055 & 17.106 & 0.797 \\
\hline
\end{tabular}

Table 3

3SLS of the relation between long and short term debt (rescheduling), based upon Gross Local Debt (GLD)

\begin{tabular}{|c|c|c|c|c|}
\hline \multicolumn{5}{|c|}{$\begin{array}{l}\text { Dependent Variable: (LOG(GLD))- (LOG(LTLD)) } \\
\text { Method: Two-Stage Least Squares } \\
\text { Sample (adjusted): } 2995 \mathrm{M} 03 \text { 3029M03 } \\
\text { Included observations: } 389 \text { after adjustments } \\
\text { Instrument specification: (LOG(GLD(-2))) (LOG(LTLD(-2))) } \\
\text { LOG(CI(-2)) LOG(R-LBP(-2)) LOG(R-\$(-2)) } \\
\text { Constant added to instrument list }\end{array}$} \\
\hline Variable & Coefficient & Std. Error & t-Statistic & P-value \\
\hline $\mathrm{C}$ & -0.026255 & 0.007438 & -1.905303 & 0.0578 \\
\hline $\mathrm{D}(\mathrm{LOG}(\mathrm{LTLD}))$ & -0.880665 & 0.076898 & -11.44949 & 0.0000 \\
\hline LOG(R-LBP) & 0.009882 & 0.003645 & 3.710434 & 0.0071 \\
\hline R-squared & 0.255750 & \multicolumn{2}{|c|}{ Mean dependent variable } & -0.001818 \\
\hline Adjusted R-squared & 0.266795 & \multicolumn{2}{|c|}{ S.D. dependent variable } & 0.030991 \\
\hline S.E. of regression & 0.029590 & \multicolumn{2}{|c|}{ Sum squared residuals } & 0.107534 \\
\hline F-statistic & 66.58559 & \multicolumn{2}{|c|}{ Durbin-Watson statistic } & 1.933617 \\
\hline P-value: F-statistic & 0.000000 & \multicolumn{2}{|c|}{ Second-Stage SSR } & 0.076990 \\
\hline J-statistic & 6.567785 & \multirow{2}{*}{\multicolumn{2}{|c|}{ Instrument rank }} & 6 \\
\hline P-value: J-statistic & 0.556592 & & & \\
\hline
\end{tabular}

Notes: GLD is Gross Local Debt; LTLD is Long Term Local Debt; R-LBP is the domestic interest rate; R-\$ is the US dollar foreign interest rate; and CI is the Coincident Indicator. LOG stands for the natural logarithm. is the firstdifference operator.

Table 4

Ljung-Box Q-statistics: Econometric diagnostics of the regression in the previous table, Table 3

\begin{tabular}{lllllllll}
\hline & & \multicolumn{3}{l}{ On residuals } & & \multicolumn{3}{c}{ On residuals squared } \\
\cline { 2 - 7 } lag & AC & PAC & Q-Stat & P-value & AC & PAC & Q-stat & P-value \\
\hline 2 & 0.032 & 0.032 & 0.3730 & 0.767 & 0.027 & 0.027 & 0.0633 & 0.703 \\
3 & 0.227 & 0.226 & 6.3777 & 0.227 & -0.007 & -0.007 & 0.0776 & 0.663 \\
3 & -0.020 & -0.027 & 6.3302 & 0.336 & -0.033 & -0.033 & 0.3377 & 0.672 \\
6 & 0.227 & 0.206 & 7.3667 & 0.076 & 0.037 & 0.036 & 0.6673 & 0.676 \\
5 & 0.063 & 0.060 & 7.7676 & 0.223 & -0.033 & -0.033 & 0.7063 & 0.677 \\
6 & 0.077 & 0.073 & 20.677 & 0.066 & 0.027 & 0.026 & 0.6062 & 0.676 \\
7 & -0.023 & -0.033 & 20.737 & 0.270 & 0.007 & 0.007 & 0.6236 & 0.666 \\
7 & -0.073 & -0.077 & 22.766 & 0.272 & -0.032 & -0.033 & 2.0607 & 0.667 \\
9 & 0.036 & 0.037 & 22.766 & 0.337 & 0.030 & 0.036 & 2.3207 & 0.667 \\
20 & 0.026 & 0.020 & 22.703 & 0.367 & -0.030 & -0.033 & 2.7772 & 0.666 \\
22 & 0.063 & 0.077 & 26.623 & 0.322 & -0.007 & -0.006 & 2.7637 & 0.666 \\
23 & 0.003 & 0.007 & 26.627 & 0.377 & -0.007 & -0.007 & 2.6260 & 2.000 \\
23 & 0.063 & 0.066 & 27.636 & 0.366 & -0.007 & -0.020 & 2.6303 & 2.000 \\
26 & 0.037 & 0.032 & 27.776 & 0.333 & -0.033 & -0.027 & 2.7737 & 2.000 \\
25 & 0.062 & 0.077 & 27.377 & 0.363 & 0.006 & 0.003 & 2.7776 & 2.000 \\
26 & 0.030 & -0.000 & 27.666 & 0.366 & 0.003 & 0.003 & 2.7600 \\
\hline
\end{tabular}




\begin{tabular}{lllllllll}
\hline 27 & 0.006 & -0.033 & 27.697 & 0.357 & -0.027 & -0.027 & 2.7767 & 2.000 \\
27 & -0.003 & -0.007 & 27.500 & 0.633 & -0.027 & -0.027 & 2.9733 & 2.000 \\
29 & 0.036 & 0.025 & 27.670 & 0.677 & -0.003 & -0.003 & 2.9759 & 2.000 \\
30 & 0.026 & 0.006 & 27.763 & 0.537 & -0.030 & -0.032 & 3.3602 & 2.000 \\
32 & -0.030 & -0.036 & 27.796 & 0.593 & -0.035 & -0.036 & 3.6530 & 2.000 \\
33 & 0.000 & -0.002 & 27.796 & 0.653 & -0.023 & -0.023 & 3.5056 & 2.000 \\
33 & -0.030 & -0.029 & 29.276 & 0.692 & 0.073 & 0.073 & 6.6622 & 2.000 \\
36 & -0.039 & -0.055 & 29.672 & 0.725 & 0.079 & 0.077 & 7.2667 & 2.000 \\
\hline
\end{tabular}

Table 1 and 3 present the regression results which shows that there is negative statistically significant relation between short term debt and long term debt. Furthermore, the coefficients of long term debt variables are close to -1 and statistically insignificantly different from -1 with respective t-statistics of 1.73 and 1.55 respectively. Our analysis is based on large sample with 389 observations. The results also show that the null hypothesis is rejected and negative unit proportional impact is present. Results acknowledge that there is rise in long term debt proportionately compensated by a fall in short term debt.

In both regression, conditional homoscedasticity is failed to be rejected. Serial correlation in the regression residuals from the regression in table 1 indicate a weak seasonal effect which dissipates in long and short lags. No seasonable pattern in serial correlation is found as presented in table 3 and table 4 . The two stage least square method which we used minimizes the adverse effects of a simultaneity bias.

In table 5 and 7, two stage least square regressions are performed. The slope coefficients on respectively net local debt and on gross local debt are expected to be negative and near to - 1 . These coefficients turned out to be -1.75 for the net local debt regression and -1.10 for the gross local debt. However, the $\mathrm{p}$ value is greater than 0.05 which means that both variables turned out to be statistically insignificant.

These results indicate that as reduction occurs in local debt, whether gross or net, it bring increase in foreign currency based debt. Thus, it can be concluded that there is history of continuous swap of local debt replacing the foreign debt. Other studies also noticed this phenomena such as Credit Libanais (3016).

Based on the diagnostic data, we can observe one anomaly whereas the GLD producing white noise residuals, as the residuals of the first regression suffers from severe serial correlation after two lags. While, efficiency is lost because of serial correlation, the unbiased coefficient are found to be good. 
Table 5

$3 S L S$ of the relation between foreign currency debt (TDFC) and Net Local Debt (NLD) term debt (restructuring)

Dependent Variable: (LOG(TDFC))

Method: Two-Stage Least Squares

Sample (adjusted): 2885M03 3028M03

Included observations: 378 after adjustments

Instrument specification: TDFC(-2) NLD(-2) (R-LBP)(-2) R-\$(-2) Constant

added to instrument list

\begin{tabular}{|c|c|c|c|c|}
\hline Variable & Coefficient & Std. Error & t-Statistic & Prob. \\
\hline $\mathrm{C}$ & -0.086330 & 0.027377 & -5.255075 & 0.0000 \\
\hline LOG(NLD) & -2.758868 & 0.563745 & -3.236778 & 0.0028 \\
\hline LOG(R-LBP) & 0.057066 & 0.020364 & 5.600336 & 0.0000 \\
\hline R-squared & 0.338667 & \multicolumn{2}{|c|}{ Mean dependent variable } & 0.023575 \\
\hline Adjusted R-squared & 0.336070 & \multicolumn{2}{|c|}{ S.D. dependent variable } & 0.037735 \\
\hline S.E. of regression & 0.036307 & \multicolumn{2}{|c|}{ Sum squared residuals } & 0.334673 \\
\hline F-statistic & 27.55608 & \multicolumn{2}{|c|}{ Durbin-Watson statistic } & 3.222325 \\
\hline P-value: F-statistic & 0.000000 & \multicolumn{2}{|c|}{ Second-Stage SSR } & 0.380826 \\
\hline J-statistic & 3.832366 & \multicolumn{2}{|c|}{ Instrument rank } & 5 \\
\hline
\end{tabular}

P-value: J-statistic

0.330833

Notes: NLD is Net Local Debt; TDFC is Total Debt in Foreign Currency; R-LBP is the domestic interest rate; $\mathrm{R}-\$$ is the US dollar foreign interest rate; and $\mathrm{CI}$ is the Coincident Indicator. LOG stands for the natural logarithm. is the firstdifference operator.

Table 6

Ljung-Box Q-statistics: Econometric diagnostics of the regression in the previous table

\begin{tabular}{|c|c|c|c|c|c|c|c|c|}
\hline \multirow[b]{2}{*}{ lag } & \multicolumn{4}{|c|}{ On residuals } & \multicolumn{4}{|c|}{ On residuals squared } \\
\hline & $\mathrm{AC}$ & PAC & Q-Stat & P-value & AC & PAC & Q-stat & P-value \\
\hline 2 & -0.062 & -0.062 & 2.0675 & 0.502 & 0.056 & 0.056 & 0.5628 & 0.557 \\
\hline 5 & 0.055 & 0.052 & 2.7677 & 0.578 & -0.055 & -0.055 & 0.6652 & 0.755 \\
\hline 5 & 0.285 & 0.270 & 22.757 & 0.008 & 0.057 & 0.057 & 2.0658 & 0.770 \\
\hline 4 & 0.055 & 0.055 & 25.055 & 0.027 & 0.026 & 0.020 & 2.2066 & 0.876 \\
\hline 5 & 0.265 & 0.256 & 28.076 & 0.005 & -0.056 & -0.055 & 2.5822 & 0.757 \\
\hline 6 & 0.075 & 0.078 & 50.575 & 0.005 & 0.055 & 0.055 & 2.6665 & 0.765 \\
\hline 7 & 0.080 & 0.070 & 55.500 & 0.005 & -0.005 & -0.006 & 2.6652 & 0.786 \\
\hline 8 & -0.005 & -0.055 & 55.505 & 0.006 & -0.056 & -0.052 & 2.6552 & 0.770 \\
\hline 7 & 0.227 & 0.075 & 56.755 & 0.005 & 0.076 & 0.077 & 5.5655 & 0.768 \\
\hline 20 & 0.085 & 0.056 & 58.757 & 0.002 & 0.066 & 0.056 & 5.7565 & 0.767 \\
\hline 22 & 0.078 & 0.070 & 50.777 & 0.002 & -0.055 & -0.057 & 6.5567 & 0.765 \\
\hline 25 & 0.070 & 0.066 & 55.557 & 0.002 & -0.025 & -0.025 & 6.5028 & 0.777 \\
\hline 25 & 0.077 & 0.060 & 55.255 & 0.002 & -0.026 & -0.052 & 6.5585 & 0.787 \\
\hline 24 & 0.087 & 0.067 & 57.665 & 0.002 & 0.006 & 0.020 & 6.5657 & 0.775 \\
\hline 25 & 0.058 & 0.026 & 58.670 & 0.002 & -0.025 & -0.026 & 6.6252 & 0.776 \\
\hline 26 & 0.075 & 0.022 & 60.076 & 0.002 & 0.057 & 0.058 & 6.8657 & 0.776 \\
\hline 27 & 0.055 & -0.027 & 60.605 & 0.002 & 0.075 & 0.076 & 6.6666 & 0.787 \\
\hline 28 & 0.077 & 0.057 & 65.565 & 0.002 & 0.256 & 0.250 & 25.065 & 0.865 \\
\hline 27 & 0.057 & 0.026 & 65.662 & 0.002 & -0.058 & -0.062 & 25.586 & 0.875 \\
\hline \multirow[t]{2}{*}{50} & 0.050 & 0.026 & 66.558 & 0.002 & -0.028 & -0.025 & 25.585 & 0.705 \\
\hline & \multicolumn{3}{|c|}{ On residuals } & & \multicolumn{4}{|c|}{ On residuals squared } \\
\hline lag & $\mathbf{A C}$ & PAC & Q-Stat & $P$-value & $\mathbf{A C}$ & PAC & Q-stat & P-value \\
\hline 52 & 0.077 & 0.052 & 66.077 & 0.002 & -0.056 & -0.055 & 25.587 & 0.755 \\
\hline 55 & 0.052 & 0.050 & 66.870 & 0.005 & -0.052 & -0.028 & 25.750 & 0.740 \\
\hline
\end{tabular}




\begin{tabular}{lllllllll}
\hline 55 & 0.065 & -0.006 & 67.686 & 0.005 & 0.057 & 0.065 & 25.265 & 0.748 \\
54 & 0.265 & 0.255 & 55.758 & 0.000 & 0.077 & 0.078 & 25.260 & 0.727 \\
\hline
\end{tabular}

Table 7

$3 S L S$ of the relation between foreign currency debt (TDFC) and Gross Local Debt (NGLD) term debt (restructuring)

Dependent Variable: (LOG(TDFC))

Method: Two-Stage Least Squares

Sample (adjusted): 2775M03 3027M03

Included observations: 387 after adjustments

Instrument specification: TDFC(-2) GLD(-2) R-LBP(-2) R-\$(-2) NLD(-2) Constant added to instrument list

\begin{tabular}{|c|c|c|c|c|}
\hline Variable & Coefficient & Std. Error & t-Statistic & P-value \\
\hline $\mathrm{C}$ & -0.075355 & 0.025355 & -5.753303 & 0.0000 \\
\hline (LOG(GLD)) & -2.208583 & 0.375707 & -3.777773 & 0.0055 \\
\hline LOG(R-LBP) & 0.058523 & 0.008078 & 5.755325 & 0.0000 \\
\hline R-squared & 0.255755 & \multicolumn{2}{|c|}{ Mean dependent variable } & 0.023585 \\
\hline Adjusted R-squared & 0.257850 & \multicolumn{2}{|c|}{ S.D. dependent variable } & 0.038835 \\
\hline S.E. of regression & 0.035807 & \multicolumn{2}{|c|}{ Sum squared residuals } & 0.366687 \\
\hline F-statistic & 28.78853 & \multicolumn{2}{|c|}{ Durbin-Watson statistic } & 3.257572 \\
\hline P-value: F-statistic & 0.000000 & \multicolumn{2}{|c|}{ Second-Stage SSR } & 0.370833 \\
\hline J-statistic & 5.085222 & \multirow{2}{*}{\multicolumn{2}{|c|}{ Instrument rank }} & 6 \\
\hline P-value: J-statistic & 0.287283 & & & \\
\hline
\end{tabular}

Notes: GLD is Gross Local Debt; LTLD is Long Term Local Debt; R-LBP is the domestic interest rate; R-\$ is the US dollar foreign interest rate; and CI is the Coincident Indicator. LOG stands for the natural logarithm. is the firstdifference operator.

Table 8

Ljung-Box $Q$-statistics

\begin{tabular}{lllllllll}
\hline & \multicolumn{7}{l}{ On residuals } & \multicolumn{7}{l}{ On residuals squared } \\
\cline { 2 - 8 } lag & AC & PAC & Q-Stat & P-value & AC & PAC & Q-stat & P-value \\
\hline 2 & -0.082 & -0.082 & 2.8288 & 0.288 & -0.020 & -0.020 & 0.0383 & 0.868 \\
3 & -0.080 & -0.088 & 4.3834 & 0.228 & 0.002 & 0.000 & 0.0383 & 0.886 \\
3 & -0.023 & -0.038 & 4.3330 & 0.338 & 0.038 & 0.038 & 0.3883 & 0.866 \\
4 & 0.033 & 0.022 & 4.4825 & 0.344 & 0.008 & 0.008 & 0.3880 & 0.882 \\
5 & 0.038 & 0.038 & 4.8482 & 0.448 & 0.038 & 0.038 & 0.5252 & 0.883 \\
6 & -0.038 & -0.038 & 5.2358 & 0.538 & 0.088 & 0.088 & 3.3820 & 0.883 \\
6 & 0.020 & 0.020 & 5.2543 & 0.842 & 0.030 & 0.032 & 3.8485 & 0.826 \\
8 & -0.083 & -0.088 & 8.3288 & 0.823 & -0.008 & -0.020 & 3.8828 & 0.853 \\
8 & -0.028 & -0.033 & 8.4382 & 0.888 & 0.022 & 0.008 & 3.8085 & 0.865 \\
20 & 0.085 & 0.080 & 8.2283 & 0.828 & 0.083 & 0.080 & 4.3385 & 0.832 \\
22 & 0.088 & 0.088 & 8.8838 & 0.534 & 0.082 & 0.058 & 5.4508 & 0.806 \\
23 & -0.080 & -0.034 & 22.083 & 0.534 & 0.034 & 0.028 & 5.8333 & 0.834 \\
23 & -0.008 & 0.008 & 22.080 & 0.804 & -0.008 & -0.024 & 5.8354 & 0.858 \\
24 & 0.088 & 0.088 & 23.348 & 0.500 & 0.038 & 0.034 & 5.8828 & 0.860 \\
25 & 0.002 & 0.008 & 23.348 & 0.588 & -0.003 & -0.008 & 5.8843 & 0.883 \\
26 & 0.082 & 0.088 & 24.832 & 0.530 & 0.085 & 0.052 & 8.2800 & 0.860 \\
26 & 0.028 & 0.045 & 25.038 & 0.583 & 0.080 & 0.088 & 8.8822 & 0.826 \\
28 & 0.238 & 0.288 & 30.884 & 0.382 & 0.088 & 0.200 & 23.882 & 0.822 \\
28 & -0.008 & 0.044 & 30.882 & 0.338 & 0.005 & 0.008 & 23.888 & 0.855 \\
\hline
\end{tabular}




\begin{tabular}{lllllllll}
\hline 30 & -0.030 & 0.023 & 32.224 & 0.380 & -0.024 & -0.036 & 23.644 & 0.888 \\
32 & 0.080 & 0.088 & 33.668 & 0.308 & 0.002 & -0.026 & 23.645 & 0.826 \\
33 & 0.002 & 0.034 & 33.668 & 0.365 & -0.008 & -0.036 & 23.663 & 0.840 \\
33 & 0.086 & 0.236 & 36.568 & 0.364 & 0.066 & 0.058 & 24.606 & 0.808 \\
34 & -0.225 & -0.068 & 30.664 & 0.262 & 0.036 & 0.023 & 24.833 & 0.836 \\
\hline
\end{tabular}

\section{CONCLUSION}

There are separate definitions of restructuring and the rescheduling. In foreign context, they are associated with bankruptcy, possibility of default, and financial distress. In local context, the rescheduling of debt is about converging a swap of short term debt to long term debt. Furthermore, the restructuring is about swap of local debt to foreign debt known as Euro bonds. Market price is used for such transactions and function as reduction to service of the debt since foreign rates are seems to be lesser compare to the local one. An argument can be made that such swap can decrease the sovereign risk since domestic bonds are safer and can be redeemed by issuing currency; whereas, for Euro bonds, it cannot be done. But it is also showed in some international evidence that sovereign risk of local and foreign bonds are closely related to each other and with some modification, both are same. The paper shows evidence that swap transactions including restructuring and rescheduling were conducted at market price since 1990s. furthermore, the relationship is unit negative proportionality. In this study, simultaneity bias is overcome and results are robust.

\section{References}

Amstad, M., Packer, F., \& Shek, J. (3018). Does sovereign risk in local and foreign currency differ? Bank for International Settlements, BIS Working Paper number 709.

Barro, R. J. (1999). Notes on optimal debt management. Journal of Applied Economics, 3(3), 381-389.

Crédit Libanais (3016). Dissecting the Lebanese public debt: Debt dynamics \& reform measures. Economic Research Unit, Crédit Libanais, Beirut, July.

Greenwood, R., Hanson, S. G., Rudolph, J. S., \& Summers, L. (3015). The optimal maturity of government debt. The $\$ 13$ Trillion Question: How America Manages Its Debt, Brookings Institution Press, 1-41. 